Editorial

\title{
Special Issue on Surveillance: Editor's Introduction
}

\author{
James Schwoch $^{1, *}$, John Laprise ${ }^{2}$ and Ivory Mills ${ }^{1}$ \\ ${ }^{1}$ Department of Communication Studies and PhD Program in Media, Technology, and Society, Northwestern University, \\ Evanston, IL 60208, USA; E-Mails: j-schwoch@northwestern.edu (J.S.), imills@u.northwestern.edu (I.M.) \\ ${ }^{2}$ Independent Scholar, Des Plaines, IL 60016, USA; E-Mail: jlaprise@gmail.com \\ * Corresponding author
}

Submitted: 15 September 2015 | Published: 30 September 2015

\begin{abstract}
\section{Keywords}

communication; media; surveillance
\end{abstract}

This Editor's Introduction discusses the interplay of surveillance issues with media and communication research.

\section{Issue}

This editorial is part of the special issue "Surveillance: Critical Analysis and Current Challenges", edited by James Schwoch (Northwestern University, USA), John Laprise (Independent Researcher) and Ivory Mills (Northwestern University, USA).

(C) 2015 by the authors; licensee Cogitatio (Lisbon, Portugal). This article is licensed under a Creative Commons Attribution 4.0 International License (CC BY).

On May 9, 1874, Edward Clark, the Architect of the United States Capitol, responded to U.S. House of Representatives Speaker James G. Blaine regarding questions about the telegraph offices and stations located in the corridors of the South Wing of the Capitol building. ${ }^{1}$ Telegraph companies had established corridor offices within the Capitol to serve a range of clientele, including Congress, the Supreme Court, Library of Congress staff, additional government personnel, reporters, and visitors. Blaine had asked Clark to recommend ways in which the "telegraph instruments" could be "so isolated that it shall be impossible for any unauthorized person to hear and obtain messages." Clark consulted with Western Union and Franklin Telegraph, both of whom ran commercial telegraph offices in these corridors. He also sent J.F. Knapp, the operator of the government telegraph for the South Capitol Wing, into the field to find out where the telegrams sent by the stations in the Capitol corridors went as they left the Capitol for relay on various lines and networks. Knapp traced message flow from the Capitol up the Eastern Seaboard to Boston. He found that many mes-

1 Clark to Blaine, 9 May 1874, "Telegraph-Offices in the Corridors of the Capitol," House of Representatives, $43^{\text {rd }}$ Congress, $1^{\text {st }}$ session, misc. doc. 269. See annex. sages went from the Capitol directly to the telegraph operators at the nearby Willard Hotel, and while the Willard telegraph men were considered reliable, where a telegram was relayed after that and whose hands and ears it passed through was indeterminable. Knapp, giving advice echoed by individuals from the commercial telegraph services, told Clark that "isolation" was effectively accomplished by equipping the corridor stations with two items: an ear-trumpet that captured and directed the sound of the key only to the operator's ear, and screens around the telegraph key that prevented the possibility of seeing the hand of the operator as he worked the key. Knapp called these security upgrades "silent instruments." Clark was also advised that a more secure system might mean the telegraph operator remained in public view, but with the hand on the key masked by a screen so as to be unseen by observers, because a telegraph operator in a secluded room "might allow people inside his office unobserved; whereas, situated in the corridor, the office is so public that an operator would not dare to do such a thing, as it would be too readily observed."

In other words: as best as can be accomplished in 1874 for the telegraph and the Capitol, try to find out who has access to the telegraph signal once the signal leaves the building, and in the meantime, muffle the 
sound of the telegraph key, obscure the hand of the telegraph operator, and last but not least-keep the operator in public view, constantly observed by others, to prevent the operator from divulging secrets behind closed doors. Good advice then and now, and a bit like a common social media experience today: lots of private texting going on all around you, with all the private texters in public view.

This little moment of secrecy, security, and surveillance regarding the telegraph experienced by the Architect of the Capitol of the United States of America 141 years ago may on the one hand seem comical, anachronistic, incredulous, or naive. Yet the little moment of Edward Clark also illustrates that the continual complexity and constructedness of secrecy, security, and surveillance is an ongoing process shaped by, among other things, ever-changing technological capabilities in conjunction with enduring issues about social relations, human behavior, specialized knowledge, and institutional imperatives. Media and communication research has long engaged aspects of surveillance, often related to media consumption. Circulation figures, audience ratings, phonograph record sales and hit lists, best-selling books, public opinion surveys, and letters to the editor remain a significant resource for monitoring and surveilling user consumption as well as user attitudes, while the techniques and approches to such research are now more often visible in such phenonena as music downloads, fan websites, and social media buzz. These forms of media monitoring and surveillance remain important, and are some of the examples of a long engagement of media and communication scholars with research on surveillance: propaganda; attitude formation; the scale, scope, and reach of information networks; media entertainment such feature films, radio programs, and TV shows. The everincreasing expansion of media and communication technologies and cultures into more and more aspects of everyday global life continues as a dynamic theme of media and communication research, and surveillance is a crucial concept for understanding media and communication in the 21st century.

The Editors of this special issue are pleased to present this collection of media and communication research articles. All of the scholars in this issue are in lively and engaged pursuit of various aspects and themes of media, communication, and surveillance.

\section{Acknowledgements}

We thank the authors whose work is published herein, the editorial board and staff of Media and Communication, and the many external reviewers who reviewed and critiqued the manuscripts submitted for this issue.

\section{Conflict of Interests}

We declare we have no known conflicts of interest.

\section{About the Authors}

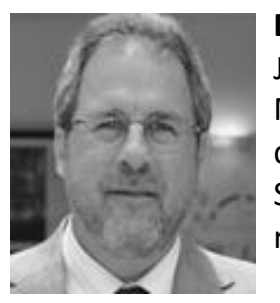

\section{Dr. James Schwoch}

James Schwoch is a Professor in the Department of Communication Studies and the PhD Program in Media, Technology, and Society at Northwestern University. His areas of research include global media, media history, international studies, global security, and media-communication-environment. Schwoch has published six books and many additional articles. His research has been funded by a variety of organizations. He is a member of the editorial board of Media and Communication.

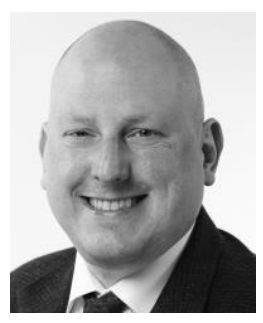

\section{Dr. John Laprise}

John Laprise is an Independent Scholar, and was a Professor at Northwestern University's Doha, Qatar campus. His areas of research include the Internet, national security, surveillance, privacy, and technology adoption. Laprise has been a visiting scholar at the Oxford Internet Institute and a consultant to the Internet Governance Forum (IGF) under the auspices of the United Nations as well as the US IGF. His PhD is from the Media, Technology, and Society Program at Northwestern University.

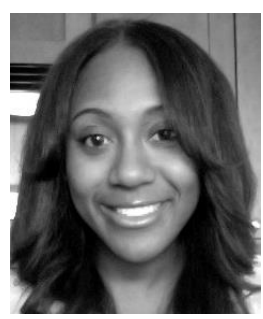

\section{Ivory Mills}

Ivory Mills is a Law \& Humanities Fellow and dual degree candidate at Northwestern, pursuing a PhD in Media, Technology, and Society and a JD at Northwestern Law. With interests in both theory and practice, she investigates international and comparative law and policy of ICT and telecommunications from an organizational and interorganizational perspective. Ivory holds a B.A. in International Studies from Spelman College and is a Fellow with the Institute for International Public Policy, Cohort 16. 
Annex. Clark to Blaine, 9 May 1874, "Telegraph-Offices in the Corridors of the Capitol," House of Representatives, 43rd Congress, 1st session, misc. doc. 269.

$\left.\begin{array}{c}\text { 430 Congress, } \\ 1 \text { st Session. }\end{array}\right\}$ HOUSE OF REPR. ENTATIVES. $\begin{gathered}\text { Mis. Doc. } \\ \text { No. } 269 .\end{gathered}$

TELEGRAPH.OFFICES IN THE CORRIDORS OF THE CAPITOL.

L E T T E R

roOM

THE ARCHITECT OF THE CAPIT'OL,

IN ANSWER TO

The resolution of the House of March 23,1874 , in relation to the telegraph . offices in the corridors of the Capitol, and making certain recommenda. tions in relation thereto.

M.1Y 9, 187.4.-Referred to the Committee on Publie Buildings and Grounds and ordered to be printed.

$$
\begin{aligned}
& \text { Arcintect's OHIICE, UNITED S'TATES CAPITOL, } \\
& \text { Washington, D. C., May 9, 1874. }
\end{aligned}
$$

Sin: 'I'o carly into effect the resolution of the House of Representa. tives passed March 23, 15i.t, "directing the Architect of the Capitol to cause the telegraph instruments located in the corridors of the south wing of the Capitol to be so isolaterl that it shall be impossible for any unauthorized person to hear and obtain messages," Sc., I have caused the wires to be examined.

It is found that in some cases these wires comnect with instruments in hotels in this city, and that all the wires comnect with various cities and stations between this and the northern cities.

In consequence of the above facts, I wrote to the oflicers of the various lines having stauds in the Capitol, singgesting certain changes, and have received replies thereto from the Western Union and the Franklin Com. panies, which are herewith submitted.

Mr. J. F. Knapp, operator of the Government telegraph for the south wing, was sent along the lines as far as the eity of Boston to make the necessary examination. His report is also herewith submitted.

As from the facts disclosed by Mr. Kuapl's report it is evident that the intended isolation of these stands will not prevent the possibility of unathorized persons obtaining messages, I resiectfully recommend that the resolution of March 23 be so modified as to require the telegraph companies to ereet suitable screens and to mufle the instruments in the manner recommended by Superintendent Smitb, of the I'ranlin Company.

I also suggest the propriety of passing a law fixing a penalty or punishment on any person who may divulge any message sent by telegraph, or intercept or take off any messages from the wires.

I am, very respectfilly, sc.,

EDVYARI) CIARK,

Hon. JAMES G. BLAINE, Architect United States Capitol. Spealer of the IIouse of Representatives. 


\title{
2 TELEGRAPII-OFFICES IN THE CORRIDORS OF THE CAPITOL.
}

\author{
'Time Wes'tern Union Telegrapil Company, \\ MaNager's OfFICE, Corner PA. AVE. LND 1.t'II S'I', \\ Washington, D. C., April 7, $18 \pi$ t.
}

DEAR Sir : I have your favor of 6th instant relative to isolation of telegraph instruments at the Capitol. All the wires of this company already run direct from the Capitol to our main oflice without passing through any' other branch.oflices. I note your' suggestion that the sound of the instruments be muftled, but I do not think it would accomplish the objuct. A more satisfactory arrangement, I think, is to dispense entirely with the sounder, which has been done in our public oflice, lear. ing the operator only his relay to read from, which reduces the sound to the minimum. necessary for his own ear. I think you will agree with me that this will effectiaily secure the ohject.

Very respectfully,

Edwand Crark, Esı., Architect, Enited states C'apitol.

$$
\text { LEONARD WIITEEY, }
$$
Menager.

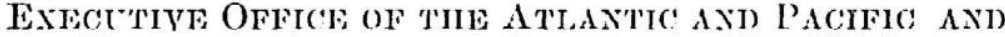

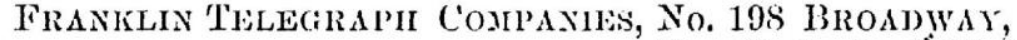 Nere Yorl, Aprit 2s, 18it.}

1)Fan Sin: On receipt of rour letter regarding the resolution of the House regarding the telegraph-oflices in the corridor of the ILouse, I inclosed the same to our manager at Washington, Mrr. Kennedy Dufl, with a letter of instructions directing him to call upon you in reference to the matter, and to take any steps that may be necessary to meet your views in this matter. My own idea of the best way to accomplish what seems to be required would be to inclose the office with suitable sur. roundings corresponding nearly to that of the present office of the Western Union Company, then to place in the office a silent instrument, comparatively ; that is, an instrument requiring an ear-trumpet leading from the instrument to the operator's ear, similar to a description of instrument used at one time by competing companies when the Western Union controlled the Morse patents. Mr. Knapp is familiar with them, and can describe them fully to you. Also to place around the hand of the operator a screen, so that the motion of his hand when transmitting cannot be observed by persons looking into the office. 'This wonld seem to me preferable to any attempt to place the operator in a secluded room, as he might, in such case allow people inside his office unobserved; whereas, situated in the corriclor, the office is so public that an operator will not dare to do such a thing, as it would be too readily observed.

Any plan that is finalls adopted will be eheerfully acquiesced in by us. Very truly, yours,

Hon. Edward Clark,

$$
\begin{aligned}
& \text { JAS. G. SMITH, } \\
& \text { Superintendent. }
\end{aligned}
$$
Architect, Cnited States Capitol.

Wasmingron, D. C., IIay 7, 1874.

SIR : As directed by you, I have examined the wires ruming from the different telegraph-oftices in the corridor of the south wing of the 
TELEGRAPII-OFFICES IN TIIE CORRIDORS OF THE CAPITOL, 3

Capitol, and (as near as I can ascertain) find that the Franklin Com. pany's wires connect with the instruments at Willard's Hotel, and the TVestern Union Company's wires, from their offico in the corridor, (from which oftice they transmit all commercial dispatches,) connect with the instruments in the reporter's gallery of both the House and Senate v 'ings of the Capitol, from which instruments messages could be taken by " unauthorized persons."

I have also examined the wires of the different telegraph eompanies between this city and Boston, and find that the Automatic 'Telegraph Company's wires only run as far as New. York City, but comnect with sereral way-stations between here and that eity, (New York.) The through wires of the Western Union and Frankilin Companies, which run through to Boston, connect with various way-stations, which stations are not allowed to use said through-wires except for test purposes, but dispatehes could be abstracted from the through-wires at these wasstations by experts.

From my observations and my practical knowledge of telegraphs, I am confident that the remoral of the offices in the corridor's of the Capitol to more private places will not render it impossible for " 111 anthorized persons" to obtain dispatches from the wires.

In conchusion, I will state that I beliere if "silent instruments"-that is, an instrument reguiring an ear.trumpet, leading from the instrument to the operatol's ear, as proposed by Superintendent Smith, of the Franklin Telegraph Company - were placed in all the oflices in the corridors of the Capitol, and sereens placed around the stands similar to that of the Western Union Company's, there would be no more danger of the abstraction of a dispatch from these stands in their present location than there would be if each were placed in a separate room. Very respectfully, yours,

Mon, EDward C'LaRK, J. F. KNAPP. Architect United s'tutes Capitol. 